\title{
THE IMPORTANCE OF THE QUALITY OF THE AGRICULTURAL PRODUCT FOR SUSTAINABLE SUCCESS OF AGRICULTURAL HOLDING
}

\author{
MILANOVIĆ Mirko", NIKITOVIĆ Zorana², VUJIČIĆ Slađana ${ }^{3}$ \\ ${ }^{1}$ Agricultural University Plovdiv, Faculty of Economics, Plovdiv (BULGARIA) \\ ${ }^{2}$ Faculty of Business Economics and Entrepreneurship, Belgrade (SERBIA) \\ ${ }^{3}$ Faculty of Business Economics and Entrepreneurship, Belgrade (SERBIA) \\ Emails:mirko@vivatravel.rs; zorana.nikitovic@vspep.edu.rs; sladjana.vujicic@vspep.edu.rs
}

\begin{abstract}
Small farms, which are mostly owned by natural persons, characterize the agricultural sector of Serbia. In order for a family farm business or holding to be successful, the following factors can be distinguished: the yield and quality of the products achieved, the prices generated for the products, and, of course, the decisions that are made in order to make the management of the farm more efficient. Given that consumers of agricultural products around the world are demanding increasing product quality, farms should work to improve competitiveness based on quality. The subject of this paper is the importance of the quality of the products for the sustainable success of agricultural holdings in the Republic of Serbia. The main goal of this paper is to provide new knowledge in the field of quality of agricultural products of agricultural holdings with the aim of achieving sustainable success.
\end{abstract}

Keywords: quality, sustainable success, agricultural holding

JEL: Q10, L15

UDC: 658.562:631

COBISS.SR-ID 28652041

\section{Introduction}

The agricultural sector in the Republic of Serbia has a very high economic and social significance, since it has a substantial share in creating the gross domestic product and employing a large number of people. Agricultural holdings are created on agricultural land and imply private ownership of the land and other means of production [21]. In 2016, agriculture accounted for $11.9 \%$ of the GDP, which is largely the result of a fertile soil and quality natural conditions for agricultural production. According to the Statistical Office of the Republic of Serbia, 680,000 people are employed in agriculture, or $21 \%$ of the total workforce in the country. In 2016, agriculture and food production accounted for $19.4 \%$ of Serbia's total exports and generated a surplus of \$1.4 billion, \$130 million more than in 2015 (mainly due to increased exports of processed fruit and vegetables). According to the results of the agricultural census in the Republic of Serbia in 2012 (the new census was in October 2018) 631,552 agricultural holdings were registered in Serbia, while the agricultural land used amounted to an area of 3.44 mil. ha. Family farms are dominant in the agricultural sector, accounting for $99.5 \%$ of the total number of agricultural holdings and $82.2 \%$ of the agricultural land used (SORS, 2013). 
According to the data of the Ministry of Agriculture (Forestry and Water Management of the Republic of Serbia), agricultural and food products have a stable share in the foreign trade exchange of Serbia, which they have maintained during 2017, with the participation of this category of products in imports increasing by 1.7 percentage points, while their participation in export decreased by 2.4 percentage points (the Republic of Serbia, the Ministry of Agriculture, Forestry and Water Management) (2018).

The data show that agriculture is one of the key economic activities of the Republic of Serbia. Livestock farming, together with crop farming, is an essential branch of agriculture in RS [1]. The increased net value of agricultural products improves indigenous investment in this sector [15].

According to the Law on Agriculture and Rural Development of the Republic of Serbia (Law on Agriculture and Rural Development of the Republic of Serbia, Art. 16), a family farm or agricultural holding is the basic form of organization of agricultural production. In the said Law, an agricultural holding is defined as a production unit where an agricultural enterprise, an agricultural cooperative, an institution or another juristic person, entrepreneur or farmer carries out agricultural production, while a family farm or holding is considered to be an agricultural holding where an individual/farmer carries out agricultural production, together with the members of his household. The Ministry of Agriculture (Forestry and Water Management of the Republic of Serbia) on the basis of the Decree on the Register of Agricultural Holdings (Off. Gazette of the Republic of Serbia, no. 45/04) from May 2004, administers the registration procedure for agricultural holdings. This register is managed by the Ministry of Finance (the Treasury Department) with the aim of improving agricultural production, increasing productivity and competitiveness.

The successful business of family farms depends on a large number of factors, but the following are the most significant: the yield and quality of their products, the prices of their products, and, of course, the decisions made in order to manage the farm more efficiently [2].

Nowadays, consumers of agro-food products around the world are demanding a better quality of products, which represents a major market challenge. Achieving quality in today's conditions requires the development of a competitiveness strategy that is based on innovation and quality.

\section{Theoretical framework}

In addition to constantly adapting to the conditions of a dynamic market and constant business improvements, today's business conditions require high-quality products from the organizations. Ensuring maximum product quality at minimal cost has become the goal of all today's organizations as quick and constant changes in today's markets alter the relationship with quality and require companies to satisfy customers in the best possible way. If we start from the definition of a product as a result of business activities, we could say that a product is the method by which each company adjusts its capabilities and available resources with the needs and requirements of the customers in a bid to satisfy them [3]. As a term, quality is used often in everyday life, and everyone has a good idea of what is good and what is poor quality [4].

Quality has now been given a prime place among the indicators of the market performance of an organization before a number of calculable parameters such as productivity, profitability, liquidity, capacity utilization, etc. Quality of service is of great importance to organizations aiming at achieving stability and success in the markets [16]. Figure 1. shows a symbolic view of the evolution of the approach from controlling and managing to improving quality and innovations in relation to product performance, process, and organization results. 
Quality has an important role in setting and defining the strategy of the organization and it is the basis for achieving competitiveness and better positioning on the market. Product quality is a multi-dimensional concept that includes the following: 1 . functionality, 2 . reliability, 3. sustainability, 4. accuracy, 5. easy handling, 6. fixability and other properties that determine the ability of the product to satisfy a particular consumer need [6], [7], [8].

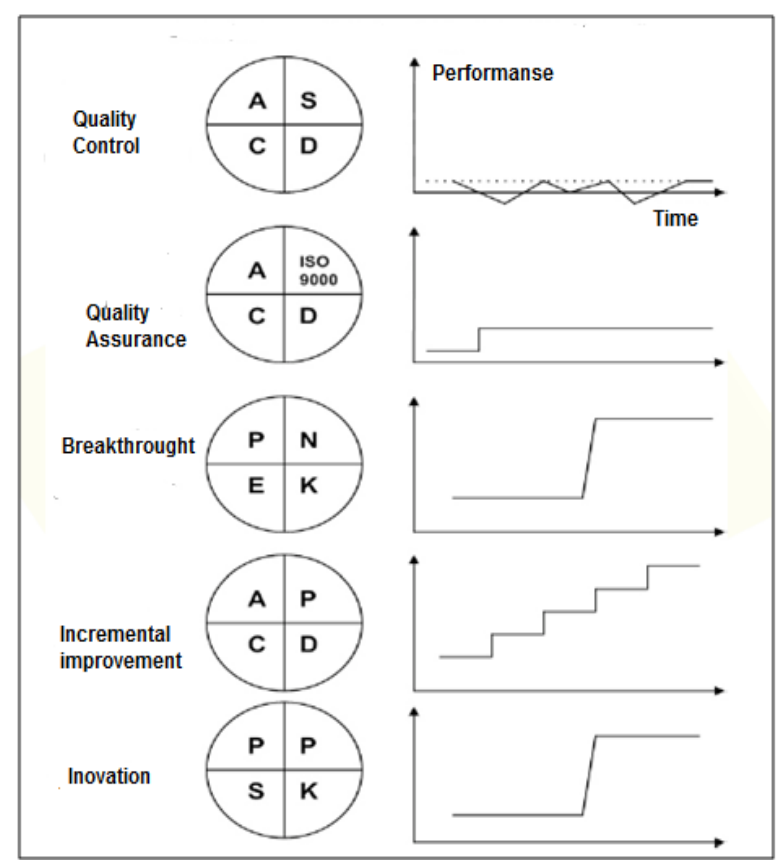

Fig. 1. Evolution from management to quality improvement and innovation. [5]

In addition to the characteristics of the product, the satisfaction of people within the organization, good interpersonal communication, communication of the organization with product users and all other stakeholders are important for quality improvement, and ensuring the satisfaction of society and the community is also important. In addition to the above, the innovation of products and processes, and constant investment in employees, their education, and training are important. Education is a very important topic addressed by a large number of authors [17], [18], [19], [20]. It can be noticed that training and education are of great importance for achieving both product quality and work processes and lead the organization towards sustainable success. (figure 2).

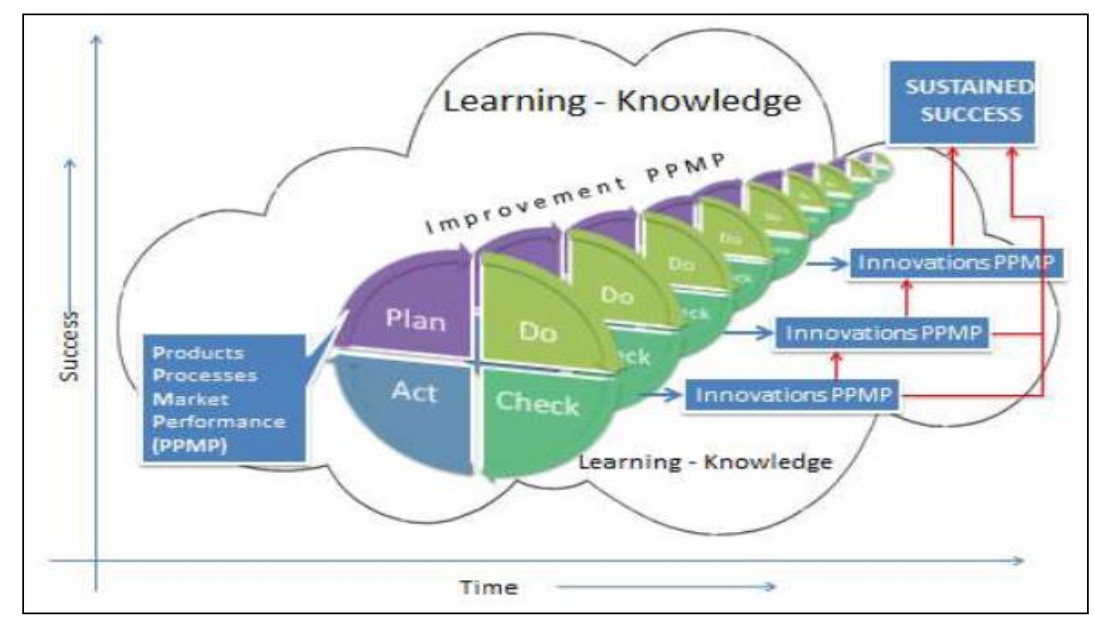

Fig. 2. Learning, knowledge and innovations lead to sustainable success Source: Adapted [9] 
Analysis and thorough understanding of the situation, good management, and continuous improvement and learning are the basis of the sustainable success of any organization.

Owners of agricultural holdings, in order to achieve the sustainability of their agricultural holdings, must have a perspective based on long-term planning, to analyze the environment of the organization, to identify all stakeholders, and to work to meet the needs and expectations of customers. In addition to effective management, long-term planning, and continuous improvement of agricultural holdings performance, in order to ensure sustainable success, agricultural holdings should work to understand the environment facing the agricultural holding, take an appropriate approach to agricultural holdings reforms, be innovative, constantly meet the needs and expectations of costumers and all stakeholders. The combination of sustainability and innovation is necessary for the realization of new combinations, which can lead to an innovative process that addresses the current sustainability challenges. Nidumolu et al., described sustainability as a key driver of innovation in the $21^{\text {st }}$ century [10].

In the development of agriculture, family farms or holdings represent the main organizational form of agriculture as a socially attractive way of agricultural production, especially the reconciliation of the increase in agricultural production with concern for the natural and sociocultural environment (Vos, Zegar, 2002; Ploeg, 2009). Of the total number of agricultural holdings, $99.5 \%$ are family farms $(628,552)$. The average economic size of agricultural holdings in the Republic of Serbia in 2012 amounts to EUR 5,939, and according to the organizational-legal form per family farm, it amounts to EUR 4,990 and EUR 204,755 by sector of legal entities and entrepreneurs.

It could be said that Serbia's agriculture is characterized by small agricultural holdings with fragmented plots of land mostly owned by individuals. Private farms dominate in agriculture in Serbia and use more than $90 \%$ of agricultural land, while the remaining $10 \%$ of agricultural land is used by state/public enterprises and cooperatives [11]. According to the Law on Agriculture and Rural Development of the Republic of Serbia (Agricultural and Rural Development Act of the Republic of Serbia), an agricultural holding is a production unit where an agricultural enterprise, agricultural cooperative, institution or other legal entity carries out agricultural production, while a family farm is an agricultural holding where a farmer, together with members of his household, carries out agricultural production.

Table 1. Agricultural production-2015-2017 indices

\begin{tabular}{|l|l|l|l|l|l|l|l|l|l|}
\hline \multicolumn{7}{|c|}{ Crop production } & \multicolumn{7}{c|}{ Livestock breeding } \\
\hline $\begin{array}{l}\text { Agriculture } \\
\text { total }\end{array}$ & All & $\begin{array}{l}\text { Crop } \\
\text { farming }\end{array}$ & $\begin{array}{l}\text { Fruit } \\
\text { growing }\end{array}$ & Viticulture & All & $\begin{array}{l}\text { Cattle } \\
\text { breeding }\end{array}$ & $\begin{array}{l}\text { Pig } \\
\text { breeding }\end{array}$ & $\begin{array}{l}\text { Sheep } \\
\text { breeding }\end{array}$ & $\begin{array}{l}\text { Poutry } \\
\text { breeding }^{3}\end{array}$ \\
\hline \multicolumn{8}{|c|}{ Chain indexes - previous year=100 } \\
\hline 92,0 & 87,3 & 83,4 & 105,0 & 139,3 & 103,5 & 100,5 & 103,8 & 102,8 & 102,6 \\
\hline 109,0 & 119,5 & 124,7 & 102,2 & 85,5 & 98,3 & 99,3 & 104,5 & 89,1 & 95,1 \\
\hline 88,1 & 76,5 & 71,9 & 94,7 & 113,5 & 101,5 & 100,3 & 100,7 & 107,4 & 102,1 \\
\hline \multicolumn{8}{|c|}{ Base indexes - 2015=100 } \\
\hline 100,0 & 100,0 & 100,0 & 100,0 & 100,0 & 100,0 & 100,0 & 100,0 & 100,0 & 100,0 \\
\hline 109,0 & 119,5 & 124,7 & 102,2 & 85,5 & 98,3 & 99,3 & 104,5 & 89,1 & 95,1 \\
\hline 96,0 & 91,5 & 89,7 & 96,8 & 97,0 & 99,7 & 99,5 & 105,2 & 95,6 & 97,1 \\
\hline
\end{tabular}

The agricultural sector of the Republic of Serbia has not yet reached its full capacity on the world market, as the results we can see are still below those that are realistically possible based on Serbia's agricultural resources. 
The Strategy for Agriculture and Rural Development of the Republic of Serbia for the $2014-2024$ period (Off. Gazette of the Republic of Serbia, no. 85/2014) points to the fact that "the market for agricultural and food products is one of the most competitive markets, where very often, in front of producers, especially those who export food to the market of EU member states, there are additional requirements for the application of certain standards, initiated primarily by large retail chains, but also by consumers." For the above reasons, there is a need to harmonize the production and marketing of food products with the requirements defined by the standards of food safety and quality (GLOBALG.AP, BRC, IFS, ISO series, Halal, Kosher, etc.) (the Agricultural and Rural Development Strategy of the Republic of Serbia for the 2014-2024 period).

As today's customers demand products that guarantee better taste and higher quality, there has been a "turn towards quality" trend in the agri-food sector in Europe, where there is also increasing movement from the industrial world (with a large number of standardized quality conventions and the logic of mass production) to "domestic production" where quality rules are embedded in trust and tradition, and products and forms of economic organization are diverse, localized and ecological [12].

In order to improve the physical and economic performance of small and medium-sized agricultural holdings in Serbia (which dominate in the structure of total farms by providing stable and high sources of income of the holding and becoming more competitive on the domestic and foreign markets), it is necessary for farmers to engage more actively on removing the internal constraints, or the development of the internal capacities of the holdings in the following areas: (a) education, acquisition of new knowledge and skills, greater awareness; (b) fostering an entrepreneurial and competitive spirit; (c) greater application of innovations in production and operations, which are not significantly related to financial resources; (d) changes in mindset and mentality in the direction of a real insight into the mistakes, problems, opportunities, needs for association, importance of investments in products with higher stages of processing, introduction of quality standards, improvement of product quality, and similar [13].

\section{The methodological postulates of the research}

In the time of a global crisis, it is important to encourage the development of agriculture through the development of its own competitiveness in order for it to be built on quality and the development of new ideas. Consumers of agricultural products around the world demand an increasing quality of products, which presents an increasing market challenge. Creating a quality product in today's market conditions demands developing a competitive strategy based on innovation and quality. Innovations in agriculture, just like in every other sector, are the main motor behind the growth of productivity [14].

Based on the findings presented in the literature review, based on the available literature (domestic and foreign), and based on specialized works in this field (Vilallobos, Garcia, Avila, 2017; Faure et al., 2018, Vogl, Kummer, Schunko, 2016; Alston, 2010; Alston et al., 2010; OECD, 2009; OECD, 2010c; OECD, 2010d; Stads, Beintema, 2012; Fuglie, 2012) a selection of questions for the poll have been selected.

The questions were created and in accordance to the ISO 9001:2015 and ISO 9004:2009 standards. Based on the analysis of the previous theoretical analysis a Basic system model has been created - The quality level of agricultural products significantly affects the level of sustainable success of individual family agricultural holdings.

Expert research was conducted on a sample of 60 experts on the territory of the Republic of Serbia (university professors, colleges, employees in public administrations at the position 
of agricultural advisers, staff employed at institutes relevant to the field of research) in the period from 1 July to 1 September, 2018.

\section{Empirical research and discussion}

The reliability of the theoretical model and questionnaire was analyzed by 60 experts from the following areas: quality and the sustainable success of agricultural holdings. The reliability of the set model can be determined or checked in two ways: based on the recommendations for the identification of factor loadings, and based on the rules and guidelines for internal consistency.

An analysis of the profile of the respondents was carried out, the reliability of the elements of the system model was established, and the benefits and justification of the research, the factor analysis of the model, and the correlation and regression analysis of the model were calculated.

Of the twenty quality components analyzed (Q1. An agricultural holding follows information regarding all stakeholders; Q2. An agricultural holding follows information regarding the requests of stakeholders; Q3. An agricultural holding reexamines the information regarding all stakeholders; Q4. An agricultural holding reexamines the information regarding all stakeholder requests; Q5. An agricultural holding secures that all the stakeholder requests are determined; Q6. An agricultural holding secures that all the stakeholder requests are understood; Q7. An agricultural holding secures that all the stakeholder requests are constantly met; Q8. An agricultural holding is focused on user satisfaction; Q9. A policy of quality is established in an agricultural holding; Q10. There is an allocation of responsibility in an agricultural holding; Q11. An agricultural holding plans riskrelated measures; Q12. An agricultural holding plans opportunity-related measures; Q13. An agricultural holding sets aims of quality; Q14. An agricultural holding keeps documented information about its products; Q15. An agricultural holding maintains the satisfaction of the users of its products; Q16. An agricultural holding produces high quality products; Q17. Customers consider products from agricultural holdings dependable; Q18. An agricultural holding has set ways of external communication; Q19. An agricultural holding has set ways of external communication; and Q20. An agricultural holding sets and selects improvement opportunities) we have proven that the most influential on the sustainability of the agricultural holding are: Q4, Q5, Q6, Q9, Q10, Q14 and Q16. An agricultural holding keeps documented information about its products (Table 2). The first 5 components have characteristic values above 1.0000: 5.2050, 2.01864, 2.1116, 1.7051, 1.3474, 1.2295 and 1.0446.

Following the analysis, we can conclude that the level of quality of the agricultural product of an agricultural holding itself affects the development of possibilities of sustainable success of an agricultural holding.

Based on the research we can conclude that there exists a big influence of quality on the sustainable success of agricultural holdings in the Republic of Serbia. In order to achieve a sustainable level of success of agricultural holdings in the Republic of Serbia, it is necessary to conduct constant education programs for the farmers about the importance of quality as well as encourage the aspiration for business practice and the importance of investing in improving quality and improving the process of production. The support of the state and the department ministry has a crucial role, through the support for introducing new technologies in agricultural holdings, subsidizing the necessary materials for agricultural holdings, providing the necessary funding for constant education of agricultural holding owners and exchanging the practices with farmers from the surrounding countries. 
Table 2. Factor Analysis Eigenvalues for the 'Quality' element

\begin{tabular}{|c|c|c|c|c|}
\hline Number & Eigenvalue & Percent & 20406080 & Cum Percent \\
\hline 1 & 5,2050 & 26,025 & & 26,025 \\
\hline 2 & 2,1864 & 10,932 & & 36,957 \\
\hline 3 & 2,1116 & 10,558 & & 47,515 \\
\hline 4 & 1,7051 & 8,525 & ] & 56,040 \\
\hline 5 & 1,3474 & 6,737 & ] & 62,777 \\
\hline 6 & 1,2295 & 6,148 & ] & 68,925 \\
\hline 7 & 1,0446 & 5,223 & ] & 74,148 \\
\hline 8 & 0,9538 & 4,769 & & 78,917 \\
\hline 9 & 0,8004 & 4,002 & & 82,919 \\
\hline 10 & 0,7218 & 3,609 & & 86,528 \\
\hline 11 & 0,5904 & 2,952 & & 89,480 \\
\hline 12 & 0,4686 & 2,343 & & 91,823 \\
\hline 13 & 0,4099 & 2,049 & & 93,872 \\
\hline 14 & 0,3579 & 1,790 & & 95,662 \\
\hline 15 & 0,2562 & 1,281 & & 96,943 \\
\hline 16 & 0,2019 & 1,009 & & 97,952 \\
\hline 17 & 0,1468 & 0,734 & & 98,686 \\
\hline 18 & 0,1155 & 0,577 & & 99,264 \\
\hline 19 & 0,0937 & 0,469 & & 99,732 \\
\hline 20 & 0,0536 & 0,268 & & 100,000 \\
\hline
\end{tabular}

Besides the previously stated, by setting the goals and politics of quality, determining and understanding the demands of the customer, fulfilling their demands, and establishing communication with them with the goal of achieving feedback about the quality of the product we could, without a doubt, achieve the sustainability of holdings in the Republic of Serbia. The innovative business of individual agricultural holdings could be achieved by following the modern solutions in agriculture through the improvement of production by using innovation. Innovative behavior and business of individual agricultural holdings through the establishment of a quality customer relationship and the development of quality also affects the achievement of sustainable success of individual agricultural holdings by fulfilling the expectations coming from its surroundings and through the establishment of strategies based on the needs if interested parties.

Based on the information we can conclude that for agricultural holdings to succeed, the responsible Ministry and the government need to increase the subsidies for agricultural holdings dedicated to the investment in improving quality. With the establishment of a system of continuous training for the owners of agricultural holdings, where they could be acquainted with the latest achievements in the field of agriculture, new technologies, exchange the experience with the farmers from other countries, they could be helped in establishing a system which would be sustainable in the long term.

\section{Conclusion}

Improving the quality of agricultural holdings can be achieved by supporting new ideas, collecting ideas from external sources by encouraging business partners to create innovations, and through a well-defined strategy for introducing quality and quality management methods.

The quality components of agricultural holdings influence the factors of improving sustainability through set strategies, knowledge development, financial management for sustainable success, incentives for the inclusion of innovation, and creative behavior.

Based on the results of the research conducted and the review of literary sources, the starting model has been confirmed that the level of the quality of agricultural products has a significant impact on the level of sustainable success of individual farms. The business of the farms through establishing a quality relationship with the buyers and developing one's own quality influences the farm to achieve sustainable success by fulfilling expectations that arise from the environment, and through setting strategies based on the needs of interested parties. 
In order to improve the sustainability of individual farms a system needs to be set up, in which to run the development of new ideas with a clearly defined strategy of quality implementation and quality management. It is crucial to develop knowledge and creativity and continuously monitor the events in agriculture, as it is the only way of securing the sustainability of modern individual farms.

\section{REFERENCES}

[1] Madžar, L. (2017), Značaj i izvozni potencijal privrede Republike Srbije sa posebnim osvrtom na stanje stočnog fonda, Škola biznisa, broj 2/2014, str. 124.

[2] Ćeranić, S., Paunović, T., Novaković, N. (2013). "Evidencija, procena, kvantifikacija i analiza poslovanja porodičnih poljoprivrednih gazdinstava," Agroznanje, vol. 14, br.1. 2013, str. 87-95.

[3] Vujičić, S., Vukadinović, S., Nikolić, I. (2011) Kvalitet kao faktor konkurentske prednosti, Svarog, $3 / 2011$.

[4] Marinković V., Senić V. (2012), "Analiza elemenata kvaliteta usluga u korporativnom bankarstvu," Ekonomski horizonti, godište 14, Sveska 1, 13-22, Ekonomski fakultet Kragujevac.

[5] Heleta, M. (2008), Menadžment kvaliteta, Univerzitet Singidunum, Beograd.

[6] Đuričić R.M., Đuričić M.M., (2015), Menadžment kvaliteta u turizmu, Visoko poslovno-tehnička škola strukovnih studija, Užice

[7] Đuričić R.M., Đuričić M. R., Đuričić M.M., (2008), Integrisani menadžment kvaliteta, "IRMIR", Užice

[8] Stikić, D., Nestić, S., Marković, D. (2011), "Kvalitet proizvoda-temelj konkurentnosti," Festival kvaliteta 2007, 34. Nacionalna konferencija o kvalitetu, Kragujevac.

[9] Luburić R. (2016) "Kvalitet i upravljanje operativnim rizikom centralnih banaka," Centralna banka Crne Gore, Podgorica, str. 73.

[10] Nidumolu, R., Prahalad, C. K., Rangaswami, M. R. (2009). Why sustainability is now the key driver of innovation. Harvard Business Review (September): pp. 56-64.

[11] Hopić, S. (2008). Ruralni razvoj u Republici Srbiji. Studija SKGO u okviru Exchange 2 projekta, EU projekat, Zajednička podrška lokalnim samoupravama.

[12] Gudman, D. (2013). "The quality 'turns' and alternative food practices: reflections and agenda," Journal of Rural Studies, 19(2013), pp. 1-7.

[13] Paraušić, V., Cvijanović D. (2014) "Ekonomska veličina poljoprivrednih gazdinstava u Srbiji i preporuka mera za njihovo osnaživanje," Završna konferencija "Primena podataka Popisa poljoprivrede 2012. u analizi stanja poljoprivrede i u planiranju agrarne politike u Republici Srbiji," Zbornik radova, ISBN-978-8686-6161-115-5.

[14] http://www.oecd.org/officialdocuments/publicdisplaydocumentpdf/?cote=TAD/CA/APM/WP(2012)19/ FINAL\&docLanguage $=$ En

[15] NAEINI Ali Bonyadi, MOSAYEBI Alireza, MOHAJERANI Neda (2019) "A hybrid model of competitive advantage based on Bourdieu capital theory and competitive intelligence using fuzzy Delphi and ISM-Gray DEMATEL (study of Iranian food industry)" International Review, ISSN 22179739, No. 1-2, Faculty of Business, Economics and Entrepreneurship, Belgrade, Serbia, pp. 21-35.

[16] ALI Abdulhasan Dile, ADIL Hamza Jasim, HAMEED Madhloom Kadhim (2019) "Evaluation of Quality of Service Provided by the Vocational Training Departmen", International Review, ISSN 22179739, No. 3-4, Faculty of Business, Economics and Entrepreneurship, Belgrade, Serbia, pp. 92-105.

[17] Ilić Đ., Janjić I., Ilić S. (2019) "Upravljanje karijerom putem karijernog avetovanja", Trendovi u poslovanju, br.14, Sveska 2/2019, Visoka škola za poslovnu ekonomiju i preduzetništvo, Beograd.

[18] Radović Marković M., Lutovac M., Vujičić S. (2016) "Efekat preduzetničkog obrazovanja na razvoj preduzetničkih sposobnosti mladih”, Trendovi u poslovanju, Br.7, Sveska 1/2016.

[19] Pavić Ž. (2019) "Edukativni model obrazovanja u oblasti zdravstvenog menadžmenta", Ekonomika vol. 65, br. 1, str. 85-94.

[20] Čukanović Karavidić M., Karavidić S., Vujičić S., (2016) "Business education and social skills to leadership competencies", International Review, br. 1-2, str. 38-45.

[21] Tošović-Stevanović Aleksandra" Ćalović Dragan, Lalić Goran, Žuža, Milena, Cvijanović Gorica (2020) "Comparative analysis of the economic potential of the small and family farms in the Republic of Serbia and Romania", Ekonomika poljoprivrede, vol. 67, br. 3, str. 667-681.

\section{Article history:}

Received 26 September 2020

Accepted 15 November 2020 